\title{
PENDAMPINGAN PEMBUATAN PRODUK HANDSANITIZER BERBASIS ALKOHOL PADA KELOMPOK PKK DESA FAJAR BARU
}

\author{
Agung Abadi Kiswandono*1, Nurhasanah², Pigo Nauli ${ }^{3}$, Rizky Prabowo ${ }^{4}$ \\ ${ }^{1,2}$ Jurusan Kimia FMIPA Universitas Lampung \\ ${ }^{3}$ Jurusan Ekonomi Fakultas Ekonomi dan Bisnis, Universitas Lampung \\ ${ }^{4}$ Jurusan Ilmu Komputer FMIPA Universitas Lampung
}

agung.abadi@fmipa.unila.ac.id, nur.hasanah@fmipa.unila.ac.id, jamiatul.akmal@eng.unila.ac.id, rizky.prabowo@fmipa.unila.ac.id

\begin{abstract}
Abstrak
Kedekatan dengan lembaga pendidikan swasta ataupun negeri seperti Universitas Lampung, Universitas Islam Negeri Bandar Lampung, Universitas Bandar Lampung dan kedekatan dengan pusat bisnis, yakni pasar tradisional Untung, minimarket dan kuliner malam memberikan peluang kepada masyarakat Desa Fajar Baru untuk dapat meningkatkan wirausaha. Produk-produk skala rumah tangga yang mempunyai peluang untuk dapat dikembangkan salah satunya adalah handsanitizer. Pada kondisi saat ini, dimana pandemi corona virus dieases (covid) 19 terus meluas, maka penggunaan handsanitizer sangat dibutuhkan sekali oleh masyarakat karena produk tersebut dapat memutus penyebaran covid 19. Tujuan dari kegiatan pengabdian kepada masyarakat ini adalah pendampingan kepada kelompok mitra, yaitu PKK (Pemberdayaan Kesejahteraan Keluarga) Desa Fajar Baru dalam bentuk pelatihan dan pendampingan pembuatan produk handsanitizer berbasis alkohol. Bentuk kegiatan yang dilakukan adalah pendampingan, pelatihan, dan praktek. Hasil dari pelatihan dan pendampingan kepada kelompok mitra adalah keterampilan dan pengetahuan dalam pembuatan produk handsanitizer. Evaluasi kegiatan dilakukan dengan pengukuran terhadap pencapaian tujuan instruksional khusus dari kegiatan yang dilaksanakan dengan parameter pengukuran menggunakan pre-test dan post-test untuk mengetahui pengetahuan umum peserta tentang pembuatan dan fungsi handsanitizer, bahan baku untuk pembuatan dan merek produk. Hasil evaluasi menunjukkan bahwa pengetahuan mitra mengalami kenaikan 30\% sampai 65\% setelah mengikuti kegiatan pengabdian masyarakat tentang pembuatan handsanitizer.
\end{abstract}

Kata Kunci : covid 19, Desa Fajar Baru, handsanitizer

\section{PENDAHULUAN}

Desa Fajar Baru adalah desa yang berada di Kecamatan Jati Agung, Kabupaten Lampung Selatan. Secara geografis, Desa Fajar Baru berbatasan dengan 1) Sebelah Timur: Desa Jati Mulyo Kecamatan Jati Agung dan Kel. Tanjung Senang dan Kelurahan Way Kandis Kecamatan Tanjung Senang Bandar Lampung, 2) Sebelah Barat:
Desa Sidosari Kecamatan Natar dan Kelurahan Rajabasa Jaya Bandar 3) Sebelah Utara: Desa Karang Anyar dan Karang Sari Kecamatan Jati Agung, dan 4) Sebelah selatan: Kelurahan Labuhan Dalam Kecamatan Tanjung Senang Bandar Lampung, Lampung Lampung (Kiswandono dkk 2020, Pemerintahan Desa Fajar Baru, 2016).

Kesehatan 
Pada kondisi pandemi Corona Virus Disease (Covid) 19 tahun ini, Lampung Selatan termasuk dalam kabupaten zona kuning, oleh karena itu penggunaan produk handsanitizer sangat dibutuhkan oleh masyarakat dalam rangka memutus mata rantai penyebaran covid 19. Corona virus dieases (Covid) 19 dengan nama resmi SARS-CoV-2 ini awalnya muncul di Kota Wuhan, Provinsi Hubei, China pada Desember 2019. Dalam waktu 5 bulan, virus ini sudah menjalar ke 210 negara dan wilayah lain di seluruh dunia. Sejak awal diberitakan adanya kasus covid 19 di Indonesia, pemerintah langsung memberikan himbauan kepada masyarakat untuk selalu berhati hati dalam menjalankan aktivitas dan menganjurkan untuk tetap dirumah dan apabila kegiatan di luar rumah agar selalu mentaati protokol kesehatan pencegahan covid 19. Salah satunya adalah dengan pemakaian handsanitizer.

Pembuatan handsanitizer berbasis alkohol merupakan salah satu produk yang diunggulkan dan disarankan untuk dipakai sebagai salah satu upaya menanggulangi penyebaran covid 19. Berdasarkan letak geografisnya, bahwa desa ini berpotensi menjadi zona merah mengingat bahwa letaknya yang dekat dengan kota provinsi, Bandar Lampung. Desa Fajar Baru juga merupakan daerah dengan jalur ramai karena terletak dipinggir jalan lintas sumaterapalembang. Belum lagi kedekatannya dengan pusat bisnis, pasar tradisional Untung, kuliner malam dan minimarket-minimarket serta pusat pendidikan di Provinsi Lampung. Oleh karena itu, sangat penting untuk diberikan edukasi berkaitan dengan penerapan kehidupan baru dengan menerapkan protokol kesehatan.

Saat ini, handsanitizer merupakan kebutuhan primer manusia terutama sesuai dengan fungsi utamanya sebagai pembasmi covid 19. Handsanitizer merupakan pembersih tangan yang memiliki kemampuan antibakteri dalam menghambat hingga membunuh bakteri (Sari dan Isadiartuti, 2006). Handsanitizer efektif terhadap penurunan jumlah angka kuman dan secara deskriptif yang paling efektif adalah hand sanitizer dengan kandungan alkohol 60\%
(Desinyanto dan Djannah, 2013). Membuat sendiri kedua produk tersebut dapat dipandang sebagai suatu kegiatan ekonomi yang cukup menguntungkan, baik untuk penghematan maupun untuk menambah penghasilan bila dikelola dengan baik dalam bentuk Home Industry. Pada sisi lain, meracik sendiri produk ini, tidak dapat dikatakan hal mudah, khususnya dalam merancang bahan baku yang sesuai dengan harapan-harapan masyarakat. Kondisi ini tentunya sangat menentukan keberlangsungan pembuatan dan produksi produk tersebut.

Disisi lain bahwa, besarnya kemauan dan semangat yang dimiliki oleh kelompok mitra, yaitu kelompok PKK (Pemberdayaan Kesejahteraan Keluarga) Desa Fajar Baru berpotensi untuk dimanfaatkan menjadi sumber peningkaan pendapatan bagi mereka. Didukung dengan dekatnya pusat bisnis, yakni pasar tradisional, pusat grosir dan minimarket. Jika hal ini dapat difasilitasi dengan training atau workshop dan penerapan teknologi tepat guna serta dukungan pemerintah terhadap masyarakat maka biaya produksi dapat ditekan sehingga manfaat didapatkan oleh masyarakat, terhindar dari wabah covid 19 dan dapat menjadi sumber pendapatan pada masyarakat.

Berdasarkan latar belakang ini, maka Tim pengabdian telah melakukan kegiatan pengabdian kepada masyarakat dalam bentuk pelatihan, edukasi dan keterampilan serta pengetahuan dalam menerapkan teknologi pembuatan handsanitizer.

\section{METODE}

Program PKM (Pengabdian Kepada Masyarakat) ini dilakukan dalam beberapa tahap seperti yang telah dilakukan oleh Kiswandono dkk (2020) dan Juliasih dkk (2020). Merujuk pengabdian yang dilakukan oleh Asmi dkk (2019), peserta pengabdian yang dilibatkan langsung berjumlah 20 orang Beberapa langkah kegiatan pengabdian ini sebagai berikut:

\section{Tahap Sosialisasi Program}

Pertama, Tim pelaksana bersosialisasi berkenaan dengan program PKM kepada kepala desa Fajar Baru dan kelompok PKK sebagai kelompok mitra. 
Sosialisasi program PKM ini dilakukan dengan bersilaturahim ke Balai Desa Fajar Baru. Melalui metode pendekatan ini diharapkan program PKM dapat diterima oleh kelompok mitra sekaligus meyakinkan mereka untuk tetap beraktifitas dengan menerapkan protokol kesehatan. Pada era new normal, mainset kelompok mitra harus diubah menjadi jiwa yang bersih melalui pola hidup bersih dan sehat. Disamping bahwa, kegiatan yang kreatif dan inovatif ini dapat mendatangkan keuntungan (Gambar 1a).

\section{Tahap Pelaksanaan}

Tahap Persiapan. Tahap ini meliputi koordinasi Tim Pengabdian Unila dengan kelompok mitra, kordinasi izin dan waktu kegiatan, juga persiapan bahan dan alat yang akan dibutuhkan dalam pelaksanaan program pengabdian.

Tahap Pelaksanaan. Tahap ini terdiri dari Sosialiasi, edukasi tentang kehidupan new normal kepada kelompok mitra (Gambar 1b) dan pendampingan pelatihan melalui demonstrasi secara langsung kepada kelompok mitra dengan metode Focus Group Discussion (FGD) mengenai pembuatan handsnitizer (Gambar 1c).

\section{Tahap Evaluasi}

Tahapan terakhir yang dilakukan adalah tahap evaluasi, yang terdiri dari: tahap pertama pada awal kegiatan, selanjutnya tahap kegiatan sedang berlangsung dan tahap akhir. Evaluasi dilakukan pada materi, acara dan keberlanjutan program. Program kegiatan meliputi materi penyuluhan dan pelatihan, teknologi yang diterapkan untuk produksi pembuatan handsanitizer (Gambar 2)

\section{Tahap Pemantauan}

Tahap ini dilakukan setelah kegiatan dilaksanakan, yaitu satu bulan dari waktu kegiatan pengabdian dilaksanakan. Hal ini dilakukan untuk melihat keberlangsungan produksi pembuatan handsanitizer serta pengelolaan dan penerapan pola hidup bersih dan sehat pada kelompok mitra.

\section{Prosedur Pembuatan Handsanitizer}

Pembuatan handsanitizer mengikuti surat edaran yang diterbitkan oleh Badan Pengawas Obat dan Makanan (BPOM) (2020). Surat edaran tersebut dikeluarkan sehubungan dengan kelangkaan dan mahalnya harga handsanitizer di pasaran.
Bahan-bahan yang digunakan adalah Etanol 96\%, Gliserol 98\%, Hidrogen Peroksida 3\% dan Air Steril atau Akuades.

Alat yang dipakai pada pembuatan handsanitizer adalah Gelas ukur 1000 mL, Gelas Kimia, Gelas ukur $50 \mathrm{~mL}$, Gelas ukur $25 \mathrm{~mL}$, Batang pengaduk dan Botol kaca.

\section{Cara Pembuatan:}

Etanol $96 \%$ sebanyak $833 \mathrm{~mL}$ dimasukkan ke dalam gelas ukur $1000 \mathrm{~mL}$. Kemudian ditambahkan 41,7 mL hidrogen peroksida 3\% ke dalam gelas ukur berisi etanol tersebut. Selanjutnya ditambahkan 14,5 $\mathrm{mL}$ gliserol $98 \%$ menggunakan gelas ukur. Pastikan sisa gliserol tidak tertinggal dengan cara membilasnya dengan air. Tambahkan air hingga $1000 \mathrm{~mL}$, aduk hingga homogen. Pindahkan campuran ke dalam botol kaca bersih dan simpan selama 72 jam untuk memastikan tidak ada kontaminasi organisme dari wadah botol. Setelah tiga hari handsanitizer siap digunakan.

\section{HASIL DAN PEMBAHASAN}

Kegiatan Pengabdian Kepada Masyarakat (PKM) yang dilaksanakan pada kelompok mitra di Desa Fajar Baru adalah pembuatan handsanitizer berbasis alkohol. Kegiatan inti dilaksankan selama dua hari, kemudian dilanjutkan dengan pemantauan dan evaluasi. Selain itu, kegiatan PKM juga diisi dengan memberikan edukasi kepada masyarakat akan pentingnya penerapan hidup sehat. Program pola hidup bersih dan sehat merupakan keharusan bagi masyarakat di era hidup normal. Pemakaian handsanitizer merupakan salah satu kebiasaan yang harus diterapkan dimasyarakat. Handsanitizer atau cairan pembersih tangan merupakan agen yang dipakai untuk membunuh kuman pemicu penyakit di tangan seperti, bakteri dan virus. Hand Sanitizer (cairan pembersih tangan) saat ini merupakan kebutuhan pokok untuk mencegah penyebaran virus corona.

Hasil kegiatan pembuatan handsanitizer berbasis alkohol terhadap kelompok mitra, kelompok PKK Desa Fajar Baru ini dapat diketahui berdasarkan hasil evaluasi yang telah dilakukan, baik melalui pre-test maupun post-test. Evaluasi kegiatan dilakukan dengan penilaian terhadap pencapaian TIK (Tujuan Instruksional Khusus). Pencapaian TIK dari kegiatan yang dilaksanakan tersebut 
menggunakan parameter pengukuran pre-test dan post-test untuk mengetahui kenaikan pengetahuan sebelum dan sesudah pelatihan, seperti terlihat pada Tabel 1 (Kiswandono dkk., 2020).

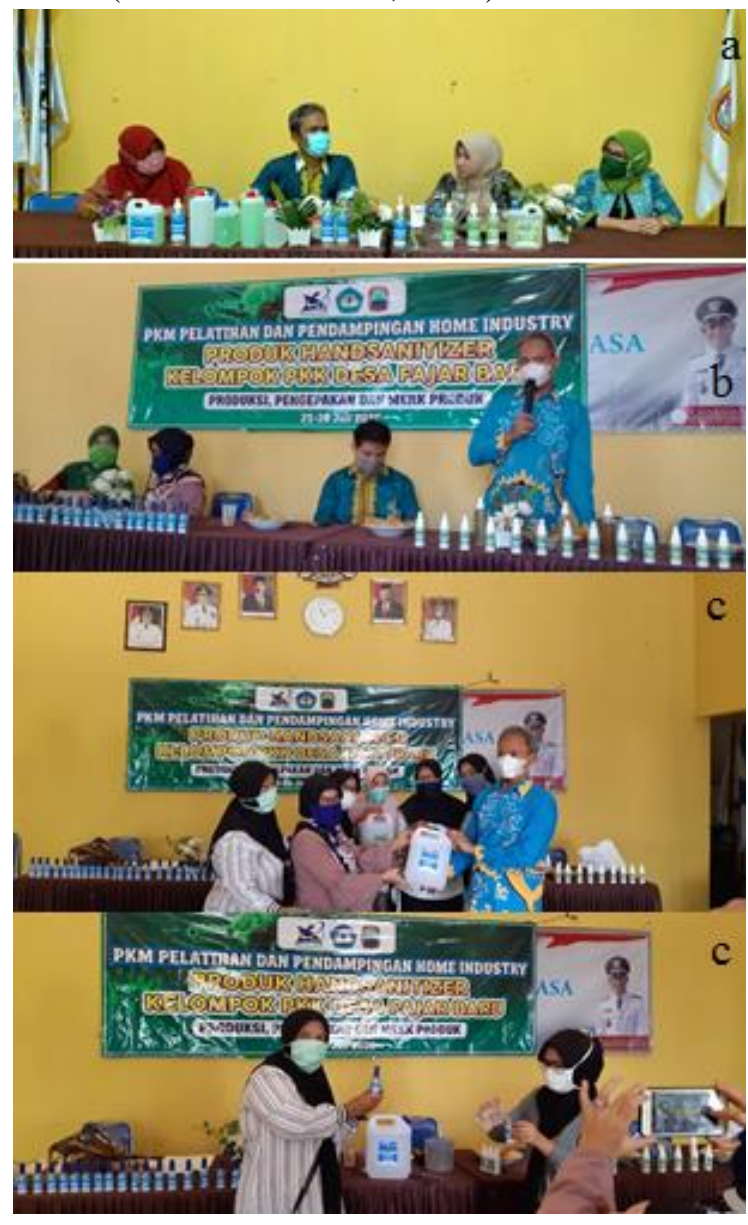

Gambar 1. (a) Sosialisasi kegiatan bersama Ketua PKK Desa Fajar Baru, (b) Sosialisasi era new normal (c) workshop pembuatan handsanitizer

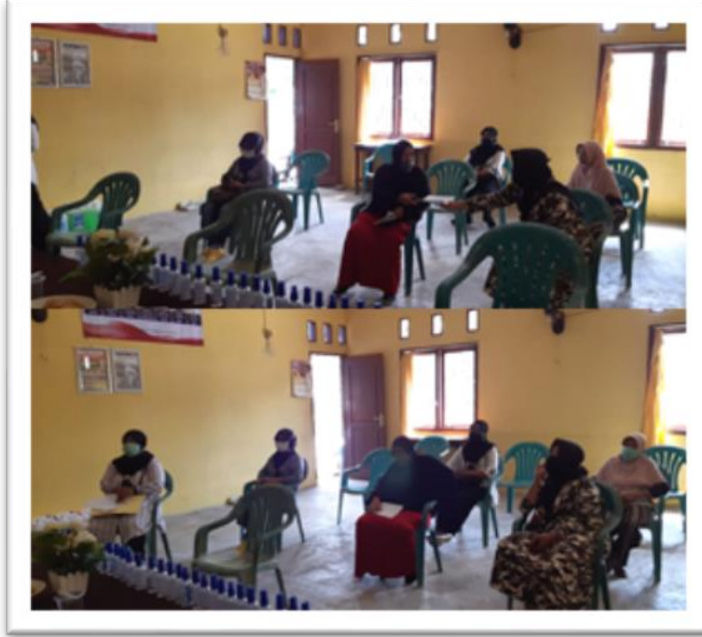

Gambar 2. Evaluasi kegiatan pada peserta

Tabel 1. Hasil TIK pre test dan post test

\begin{tabular}{|c|c|c|c|c|}
\hline \multirow[b]{2}{*}{ No } & \multirow[b]{2}{*}{ TIK } & \multicolumn{3}{|c|}{ Pencapaian TIK $(\%)^{*}$} \\
\hline & & $\begin{array}{l}\text { Pre- } \\
\text { Test }\end{array}$ & $\begin{array}{l}\text { Post- } \\
\text { Test }\end{array}$ & $\begin{array}{c}\text { Peningkatan } \\
(\%)\end{array}$ \\
\hline 1 & $\begin{array}{l}\text { Pengetahuan } \\
\text { umum peserta } \\
\text { tentang } \\
\text { manfaat } \\
\text { alkohol dan } \\
\text { fungsi bahan- } \\
\text { bahan pembuat } \\
\text { handsanitizer }\end{array}$ & 60 & 90 & 30 \\
\hline 2 & $\begin{array}{l}\text { Pengetahuan } \\
\text { umum peserta } \\
\text { tentang cara } \\
\text { pembuatan } \\
\text { handsanitizer }\end{array}$ & 40 & 92,5 & 52,5 \\
\hline 3 & $\begin{array}{l}\text { Pengetahuan } \\
\text { peserta tentang } \\
\text { fungsi } \\
\text { handsanitizer }\end{array}$ & 32,5 & 80 & 47,5 \\
\hline 4 & $\begin{array}{l}\text { Pengetahuan } \\
\text { peserta tentang } \\
\text { bahan baku } \\
\text { untuk } \\
\text { pembuatan } \\
\text { handsanitizer } \\
\text { berbasis } \\
\text { alkohol }\end{array}$ & 25 & 90 & 65 \\
\hline
\end{tabular}

Masing-masing TIK pada Tabel 1 menunjukkan kecenderungan terjadi peningkatan dengan prosentase peningkatannya yang bervariasi. Pada Tabel 1 dapat dilihat bahwa, Pengetahuan umum peserta tentang manfaat alkohol dan fungsi bahan-bahan pembuat handsanitizer terjadi peningkatan pengetahun peserta sebesar 30\%. Artinya bahwa, beberapa dari peserta yang sebelumnya tidak mengetahui fungsi dan nama bahan pembuat handsanitizer, tetapi setelah selesai pelatihan, terjadi peningkatan $30 \%$ peserta mengetahuinya, yaitu ada enam peserta. Demikian

Kesehatan

449 
pula dengan pengetahuan yang lain pada point dua, tiga dan empat. Sehingga secara umum, pengetahuan peserta setelah mengikuti pelatihan mengalami peningkatan. rata-rata sekitar $30 \%$ sampai $65 \%$. Secara umum, pengetahuan masyarakat tentang "PKM pendampingan dan pembuatan handsanitizer berbasis alkohol kelompok PKK Desa Fajar Baru Lampung Selatan" telah meningkat. Selanjutnya, harapan dari pengabdian ini juga agar peningkatan pengetahuan anggota PKK ini nantinya dapat disosialisasikan ke masyarakat Desa Fajar Baru secara umum, sehingga dengan demikian program pengabdian dapat bersinergi dalam peningkatan kesadaran penerapan pola hidup bersih dan sehat dengan penggunaan handsanitizer. Handsanitizer yang mengandung alkohol atau etil alkohol juga dapat berfungsi seperti antiseptik.

Proses pembuatan handsanitizer berbasis alkohol membutuhkan cara pengukuran yang tidak mudah serta alat dan bahan kimia yang tidak mudah ditemukan, bahkan cenderung asing di telinga orang awam. Pada pengabdian ini alkoholyang digunakan adalah etanol $96 \%$. Karena alkohol mudah terbakar dan beresiko terminum, maka dianjurkan tidak menyimpan alkohol di rumah. Jika terminum dapat menanggung resiko kerusakan otak yang serius dan permanen (Coleman dan Vernon, 1993).

Selanjutnya, untuk memastikan kebersihan larutan handsanitizer, juga digunakan hidrogen peroksida 3\%. Bahan ini berfungsi untuk membunuh kuman penyakit yang mungkin ada di dalam larutan. Sama seperti alkohol, hidrogen peroksida juga tidak dianjurkan ada di dalam rumah, karena cairan ini bisa merusak kulit bila mengenai kulit secara langsung. Terakhir bahan yang digunakan adalah gliserol. Dengan Proses pembuatan handsanitizer seperti pada prosedur yang diterbitkan oleh BPOM (2020), akan didapatkan produk handsanitizer yang dapat membunuh covid 19. Dengan tingkat ketelitian yang tinggi ketika mencampurkan bahan-bahan untuk menghasilkan handsanitizer dengan kandungan alkohol yang tepat dan bebas dari kuman.

Kemudian, berdasarkan hasil evaluasi yang telah dilakukan, terhadap produk yang telah dihasilkan, dapat disimpulkan bahwa kegiatan ini telah berhasil dan difahami kelompok mitra.
Keberhasilan ini dikarenakan, bahwa produk handsanitizer yang dihasilkan (Gambar 3) merupakan produk yang dapat digunakan untuk usaha kelompok mitra pada khususnya, dan dapat menjadi sumber pendapatan bagi masyarakat Desa Fajar Baru pada umumnya. Selain itu, bahwa masyarakat sangat mengharapkan diadakan kegiatan pembinaan dan pelatihan untuk produk home industri lainnya yang dapat meningkatkan keterampilan dan pendapatan masyarakat.

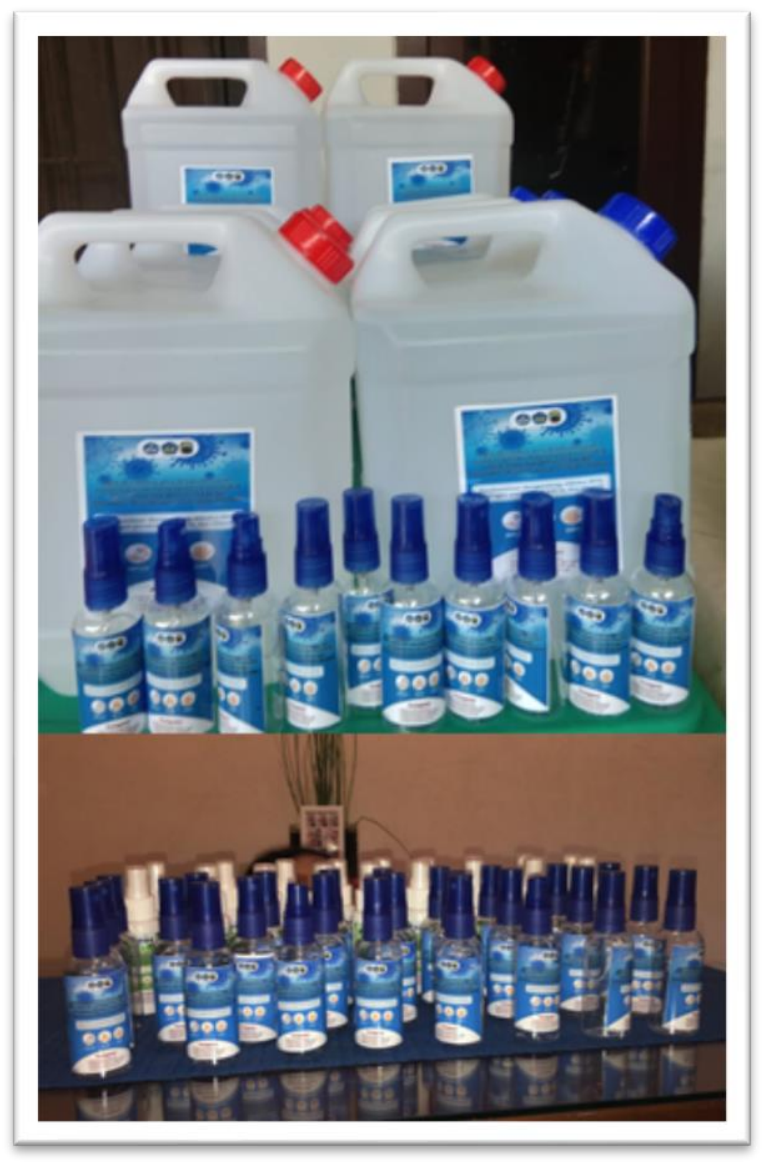

Gambar 3. Beberapa produk handsanitizer yang dihasilkan oleh kelompok mitra

Produk handsanitizer yang dihasilkan dari pelatihan ini merupakan salah satu pembersih tangan dengan kualitas yang baik. Hal ini dikarenakan bahwa pembuatan handsanitizer berbasis alkohol mengikuti prosedur yang diterbitkan oleh WHO (World Health Organization) (2010) dan surat edaran tentang pembuatan handsanitizer dari BPOM 
(2020). Sehingga dengan demikian, pembuatan handsnitizer ini dapat ditindaklanjuti menjadi kegiatan profit oleh kelompok mitra.

\section{KESIMPULAN}

Melalui kegiatan pendampingan ini, pengetahuan ibu-ibu PKK Desa Fajar Baru telah meningkat antara $30 \%$ sampai $65 \%$. Pengetahuan umum peserta tentang manfaat alkohol dan fungsi bahan-bahan pembuat handsanitizer telah meningkat sebesar 30\% sementara Pengetahuan peserta tentang bahan baku untuk pembuatan handsanitizer berbasis alkohol meningkat sebesar 65\%. Berdasarkan evaluasi juga didapatkan bahwa hampir semua peserta pelatihan menginginkan agar adanya pendampingan program kerja secara kontinyu pada mitra. Tim pengabdian merekomendasikan kepada kelompok mitra agar kegiatan ini dapat dilanjutkan dalam bentuk usaha produktif.

\section{UCAPAN TERIMAKASIH}

Setelah berjalannya kegiatan pengabdian kepada masyarakat ini, Tim Pengabdian mengucapkan terima kasih kepada Kementrian Pendidikan dan Kebudayaan (Kontrak Pengabdian No. 3537/UN26.21 /PM/2020, Tanggal 26 Mei 2020), LPPM Universitas Lampung, dan Kepala Desa, Ibu Ketua PKK dan Perangkat Desa Fajar Baru.

\section{REFERENSI}

Asmi D., Kiswandono, A.A., dan Yulianti, Y. (2019). Pelatihan Pembuatan Cinderamata Gantungan Kunci Menggunakan Material Resin Bagi Para Ibu Rumah Tangga di Desa Wisata Braja Harjosari Lampung Timur. Jurnal Sakai Sambayan. Volume 3, No. 1. $43-46$

Badan Pengawas Obat dan Makanan. (2020). Pembuatan Hand Sanitizer Dalam Upaya Mencegah Virus Corona. Surat Edaran 11 Maret 2020. Jakarta.
Coleman \& Vernon. (1993). Resiko Kerusakan Otak, Yogyakarta : penerbit Kanisius

Desinyanto, F.A. dan Djannah, S.N. (2013). Efektivitas Mencuci Tangan Menggunakan Cairan Pembersih Tangan Antiseptik (Hand Sanitizer) Terhadap Jumlah Angka Kuman. Jurnal Kesehatan Masyarakat. Vol. 7. No. 2. 75-82.

Kiswandono, A.A., Nurhasanah, dan Akmal, J. (2020). Pelatihan dan Pendampingan home industri kelompok PKK Desa Fajar Baru: Pembuatan Detergen Cair. Jurnal Sakai Sambayan. Volume 4, No. 1. 72-77

Kiswandono, A.A., Nurhasanah, dan Akmal, J. (2020). Workshop Peningkatan Kemampuan Pembuatan Detergen Cair Sebagai Upaya Mengaktifkan Pengurus PKK Desa Fajar Baru. Jurnal Apteknas. Volume 3, No. 1. 1217

Juliasih, N.R.G., Kiswandono A.A., Nauli, P., dan Nurhasanah. (2020). Teknik Pemasaran Sabun Cair Cuci Piring Chemlight Berbasis Online Di Desa Fajar Baru Lampung Selatan. Jurnal Apteknas. Volume 3, No. 1. 18-23

Pemerintahan Desa Fajar Baru. (2016), Profil Desa Fajar Baru.

Sari, R., dan Isadiartuti, D. (2006). Studi efektivitas sediaan gel antiseptik tangan. Majalah Farmasi Indonesia. Volume 17. No. 4

World Health Organization (WHO). (2010). Guide To Local Production: Who-Recommended Handrub Formulations. Page 1-9. 